\title{
Is it possible to acoustically identify individuals within a population?
}

\author{
Michał Budka $\cdot$ Lucyna Wojas • Tomasz S. Osiejuk
}

Received: 18 August 2014/Revised: 28 September 2014/Accepted: 28 November 2014/Published online: 23 December 2014

(C) The Author(s) 2014. This article is published with open access at Springerlink.com

\begin{abstract}
Acoustically identifying individuals may be a helpful technique when it is necessary to monitor animal populations over space and time. Previous studies have largely focused on the theoretical exploitation of vocal individuality or have looked at a small number of individuals. Here, we examined whether vocal individuality can be used to track the movement of individuals within a population (in this case when the number of individuals is greater than 100) and unknown beforehand. As a model species, we used the Corncrake (Crex crex) - a highly secretive bird whose calls are characterized by an individual-specific feature: pulse-to-pulse duration (PPD). When we performed classical discriminant function analyses on PPD, we correctly identified a high percentage of individuals $(>98 \%)$, even when sample size was larger than 100. However, a comparison of PPD similarity within and between individuals showed that, while birds can be correctly discriminated, unambiguous identification is impossible when the number of individuals is unknown beforehand. Therefore, we were only able to assess the probability that two calls belonged to the same individual. The results of this study show that acoustic identification in the Corncrake, and probably in other animal species, is mainly useful in detecting general behavioral patterns within populations. For instance, we discovered that more than $50 \%$ of males change territories during the breeding season, probably to find females. Physical marking
\end{abstract}

Communicated by F. Bairlein.

M. Budka $(\bowtie) \cdot$ L. Wojas · T. S. Osiejuk Department of Behavioural Ecology, Faculty of Biology, Institute of Environmental Biology, Adam Mickiewicz University, Umultowska 89, 61614 Poznan, Poland e-mail: m.budka@amu.edu.pl methods seem to be more reliable to tracking specific individuals. However, those methods usually consider limited numbers of individuals. Therefore, generalizing results to the population scale can also be misleading.

Keywords Vocal individuality - Vocal signature . Acoustic discrimination · Acoustic identification · Tracking individuals $\cdot$ Corncrake

\section{Zusammenfassung}

Ist es möglich, Individuen innerhalb einer Population akustisch zu identifizieren?

Eine akustische Identifikation von Individuen könnte eine nützliche Methode darstellen, wenn es nötig ist, Tierpopulationen über Raum und Zeit zu beobachten. Vorherige Studien haben sich weitgehend darauf konzentriert, stimmliche Individualität theoretisch zu erschließen, oder haben nur eine geringe Zahl von Individuen betrachtet. Hier haben wir untersucht, ob stimmliche Individualität dazu genutzt werden kann, die Bewegungen von zuvor unbekannten Individuen innerhalb einer Population zu verfolgen (d.h. wenn die Individuenzahl größer als 100 ist). Als Modellart haben wir den Wachtelkönig (Crex crex) gewählt, einen ausgesprochen heimlichen Vogel, dessen Rufe durch ein individuelles Merkmal gekennzeichnet sind - die Dauer zwischen Pulsen (PPD). Klassische Diskriminanzfunktionsanalysen der PPD konnten einen hohen Anteil der Individuen ( $>98 \%$ ) korrekt identifizieren, selbst wenn die Stichprobengröße 100 überschritt. Ein Vergleich der PPD-Ähnlichkeit innerhalb von und zwischen Individuen zeigte jedoch, dass, obwohl zwischen den Vögeln korrekt unterschieden werden konnte, eine eindeutige Identifizierung unmöglich ist, wenn die Individuenzahl im 
Voraus nicht bekannt ist. Daher war es uns lediglich möglich, die Wahrscheinlichkeit abzuschätzen, dass zwei Rufe vom selben Individuum stammen. Die Ergebnisse dieser Studie zeigen, dass eine akustische Identifikation beim Wachtelkönig - und wahrscheinlich auch bei anderen Tierarten - hauptsächlich dazu nützlich ist, generelle Verhaltensmuster innerhalb von Populationen zu ermitteln. Zum Beispiel haben wir herausgefunden, dass mehr als $50 \%$ der Männchen während der Brutsaison ihr Territorium wechseln, wahrscheinlich, um Weibchen zu finden. Markierungsmethoden sind offenbar zuverlässiger, um bestimmte Individuen zu verfolgen. Diese Methoden erfassen normalerweise jedoch nur eine begrenzte Zahl von Individuen, so dass eine Verallgemeinerung von Ergebnissen auf die Populationsebene ebenfalls irreführend sein kann.

\section{Introduction}

To effectively protect and manage animal populations, it is necessary to understand many aspects of species biology and ecology, such as habitat preferences, territory size, dispersion patterns, social interactions, foraging, reproduction, and survival. To acquire this knowledge, the locations and movements of animals should be tracked across reproductive seasons or even across many years (Doucette 2010; Lopes et al. 2013; Hays et al. 2014). In biological studies, individuals are usually physically marked and tracked using radio transmitters (Doucette 2010), satellite loggers (Kennedy et al. 2014), geolocators (Bächler et al. 2010), colored and numbered bands (Lopes et al. 2013; Neubauer et al. 2012), tags (Ale et al. 2011), medical cautery units (Ekner et al. 2011), tattoos or dyes (Nietfeld et al. 1994). Physically marking animals requires time, effort, and resources, and researchers have to catch an individual at least once. As a result, these marking methods are relatively expensive, and usually only a limited number of individuals can be marked and effectively tracked. Moreover, catching birds during the breeding season may cause disturbances in behavior with often unknown consequences. Alternatively, naturally occurring markers, based on phenotypic or genotypic variation, can also be used to identify individuals. Individually specific features like DNA (Jeffreys et al. 1985), fingerprints (Wahab et al. 1998), specific plumage patterns (Skórka et al. 2006; Tsuji et al. 2013; Walker et al. 2013), or song (van Opzeeland and van Parijs 2004; Adi et al. 2010; Xia et al. 2012; RootGutteridge et al. 2014) are recommended means of discriminating between and identifying individuals. In this context, it is worth pointing out the difference between the terms discrimination and identification. Discrimination is limited to census-type tasks and allows researchers to distinguish among individuals at given point in time. In contrast, identification allows individual organisms to be monitored over space and time and can yield more useful, conservation-related information on the life history of individuals (Terry et al. 2005).

It has been suggested that individual vocal features could be helpful in both monitoring and censusing efforts (Darden et al. 2003; Terry et al. 2005), especially for secretive and cryptic species (Rebbeck et al. 2001; Grava et al. 2008). This non-invasive identification method does not require capturing, visually observing, or physically approaching individuals. A recording of a call is all that is needed to identify an individual. As a result, a number of individuals can be acoustically monitored and tracked in this easy and fast way. Despite the many advantages that the use of vocal individuality may present in monitoring and conservation efforts, previous studies have largely focused on the theoretical use of vocal individuality (Terry and McGregor 2002; Klenova et al. 2008); it has only sporadically been used as a biometric marker (e.g., Hoodless et al. 2008; Mikkelsen et al. 2013). Moreover, most studies have examined fewer than 30 individuals and have not considered the possibility that two individuals might be acoustically indistinguishable (Rebbeck et al. 2001; Garcia et al. 2012). Because signal coding possibilities are finite, it becomes more likely to come across two acoustically indistinguishable individuals as sample size increases. Hence, the high classification rate obtained in studies based on small sample sizes is unlikely to be replicated in studies with large sample sizes. Furthermore, the statistical methods used to classify individuals usually require knowing the number of individuals that produced the analyzed calls (e.g., discriminant function analysis; Rognan et al. 2009; Xia et al. 2012). When censusing or monitoring wild populations, researchers rarely know the actual number of individuals that have been recorded; indeed, the same individual might be recorded many times during a monitoring session, as was the case in a study of male Woodcock (Scolopax rusticola) courtship flights (Hoodless et al. 2008).

The aim of this study was to determine whether vocal individuality could be used as a practical tool with which to track the movements of individuals. We hypothesized that, because call characteristics show lower within- than between-individual variation, and because this variation is stable over the course of an individual's life, vocal individuality could be used to track individuals within a population (in this case, more than 100 individuals). To test this hypothesis, we used the Corncrake (Crex crex)-a territorial, migratory bird species (Rallidae: Gruiformes). Corncrakes inhabit wet meadows in Europe and Asia and winter in Africa. The males are vocally active at night (Green et al. 1997) and produce an unlearned, loud call 
Fig. 1 Spectrogram of a Corncrake's (Crex crex) territorial call. The call consists of a first (S1) and a second (S2) syllable that are separated by a within-call interval (II). Calls themselves are separated by a between-call interval (I2). Each syllable contains $12-24$ pulses. The time between two consecutive pulses, called the pulse-to-pulse duration (PPD), is individual-specific and remains constant throughout a bird's life
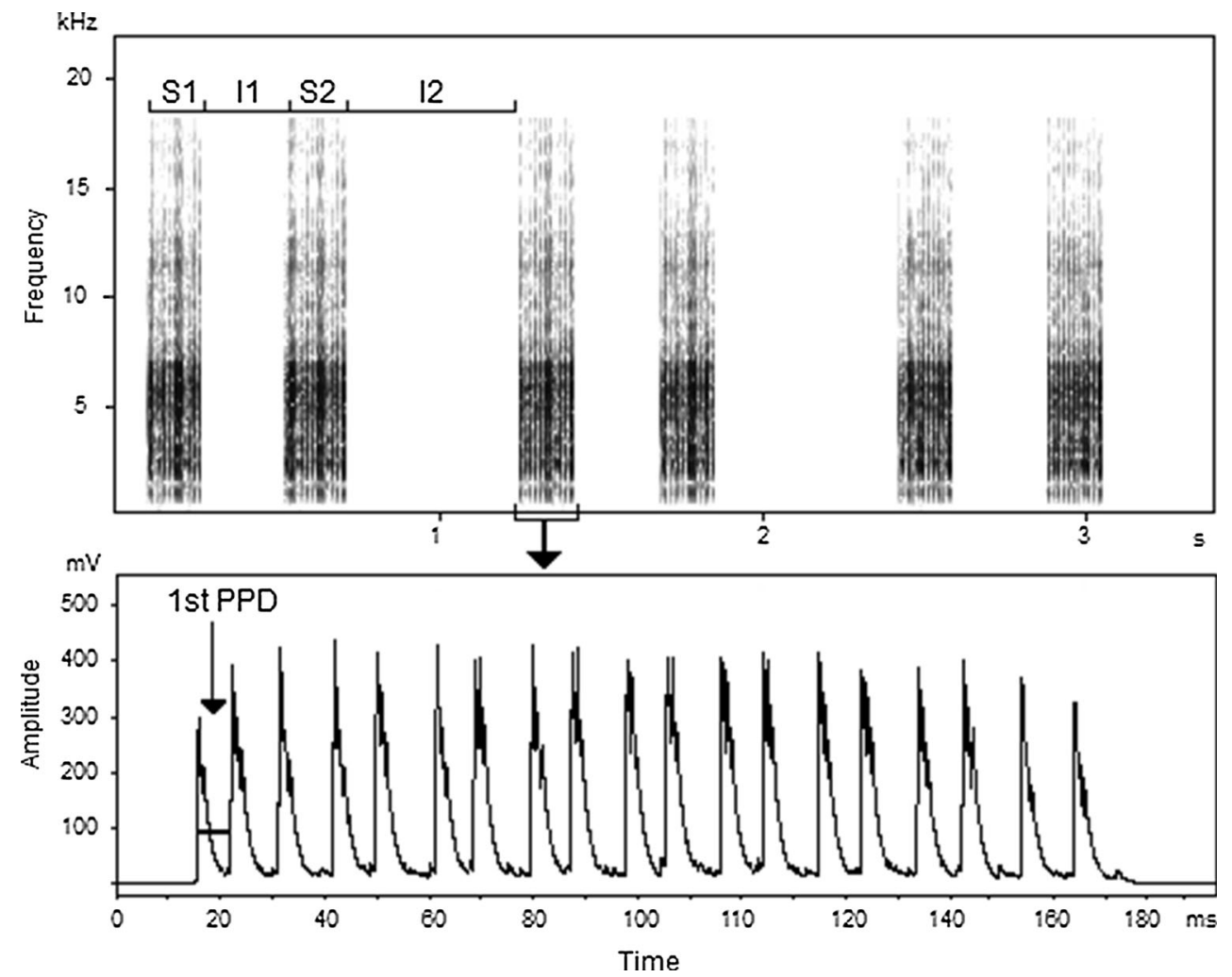

(approximately $95 \mathrm{~dB}$ SPL at $1 \mathrm{~m}$; Ręk and Osiejuk 2011b). This call has a very simple structure: it consists of two syllables that are repeated monotonously throughout the night. Each syllable usually contains 11-24 amplitude peaks, called pulses (Fig. 1). Pulses last 3-5 ms on average and are separated by intervals of $4-8 \mathrm{~ms}$. The time from the start of one pulse to the start of the next pulse (the pulse-to-pulse duration; PPD hereafter) varies less within than between individuals and does not change over the course of a given bird's life (Peake et al. 1998). Moreover, PPD-encoded information is not lost as a call is propagated through the Corncrake's natural habitat, which means that individuals can be correctly identified even from long distances (Ręk and Osiejuk 2011a). Therefore, in the past, PPD has been used to discriminate between and identify male Corncrakes (Peake and McGregor 2001; Terry and McGregor 2002; Mikkelsen et al. 2013).

In the present study, we used vocal individuality to track the movements of individuals within a population; the number of individuals was not known beforehand. First, we constructed a theoretical model using recordings obtained from individually marked males. This model estimated variation in PPD both within and between individuals, as well as the probability of correctly identifying a large number of individual birds. Afterwards, we applied what we had learned from the model to determine (1) the number of males that abandoned or changed their territories during the breeding season, and (2) the distances that males moved during the breeding season.

\section{Methods}

\section{Call recordings}

Male Corncrake calls were recorded during the breeding season (May 17-June 30, 2011 and 2012) in Poland and the Czech Republic. Each male was recorded for 2-5 min from a distance of approximately 5-15 m. Recordings were made at night (2100-0400 hours; local time) using a Marantz PMD 620 recorder and Sennheiser ME 67 directional microphones equipped with K6 power modules. We did not playback calls to provoke males into calling. The exact locations of the calling males were recorded using a Garmin GPS unit.

We collected two sets of sound data. The first set contained 122 recordings from individually marked males (numeric metal bands); these recordings were collected at three sites in Poland (Bieszczady: $49.30^{\circ} \mathrm{N}, 22.05^{\circ} \mathrm{E}$, $n=32$; Mazury: $54.30^{\circ} \mathrm{N}, 20.41^{\circ} \mathrm{E}, n=31$; Nurzec River Valley: $52.60^{\circ} \mathrm{N}, 23.22^{\circ} \mathrm{E}, n=37$ ) and one site in the Czech Republic (Orlickie Zahori: $50.27^{\circ} \mathrm{N}, 16.50^{\circ} \mathrm{E}$, $n=22$ ). This large set of recordings was used to estimate within- and between-individual variation in PPD. The 
second set contained 330 recordings collected exclusively in the Nurzec River Valley over the course of a single breeding season (2012). The Nurzec River Valley is an important area for birds in eastern Poland; it includes around $46 \mathrm{~km}^{2}$ of drained, farmed meadows. A large percentage of the meadows $(\sim 60-70 \%)$ is mown each year (Budka and Osiejuk 2013). Consequently, Corncrakes may leave their territories during the breeding season because of natural breeding behaviors or because of habitat loss due to mowing. In the Nurzec River Valley, we recorded male Corncrakes twice during the breeding season (from May 17 to June 29, 2012). Field assistants visited habitats in which Corncrakes are known to occur and recorded naturally calling males. From all the recordings collected in the Nurzec River Valley in 2012, 35 belonged to individually marked males (numeric metal rings). As a result, the minimum number of calling males within the study area was equal to or greater than 35 and the maximum number was equal to or lower than 330 .

\section{Sound analysis}

We analyzed the sound files using Avisoft SASLab Pro v.5.2.04 (Specht 2007). From each recording, we randomly selected the first continuous series of 20 calls (CALL $=$ $\mathrm{S} 1+\mathrm{I} 1+\mathrm{S} 2$; see Fig. 1) that did not contain any significant background noises. The PPDs of the first and second syllables are highly and significantly correlated in the Corncrake (Pearson's $R>0.96 ; p<0.0001$; Budka et al. 2014). As a result, we only measured PPD within the first syllable.

Before measuring PPD, we used the FIR time-domain filter $(500 \mathrm{~Hz}$; high pass setting) to remove low-frequency noises from all the sound files. Then, we used a pulse train analysis and applied the 'rectification + exponential decay' envelope method to automatically measure PPD. For most files, we used the following settings: time constant $=1 \mathrm{~ms}$, threshold $=0.10 \mathrm{~V}$, hysteresis $=10 \mathrm{~dB}$, and start/end threshold $=-8 \mathrm{~dB}$. However, for a few sound files, we had to decrease the threshold to $0.05 \mathrm{~V}$ and set hysteresis to between 8 and $12 \mathrm{~dB}$ to correctly detect all the pulses. Each syllable was measured separately, and each pulse distribution measurement was visually checked to ensure that all the pulses had been detected.

\section{Statistical analyses}

In our sample, we observed that each male produced at least 12 pulses within the first call syllable. Therefore, in the analyses, we only used the first 11 PPDs of the first syllable because this was the number of PPDs observed in the calls of all males. We calculated within-individual similarity for each male using these 11 PPDs. In the recordings from a few males, we observed that some syllables (from 1 to 4 ) were very poorly correlated with other syllables produced by the same male. Such a low degree of correlation could have been caused by rapid wind blow, head movement or sporadic imperfect syllable production. We therefore removed these atypical syllables from the dataset and measured the next syllables on the recording.

First, we determined whether individuals can be distinguished from each other using these 11 PPDs and we assessed how accurately individuals can be identified as sample size increases. We used the set of recordings from the 122 individually identified males and performed a series of discriminant function analyses (DFAs) using the following procedure. We randomly selected samples from the full dataset. The first sample contained ten individuals; we then progressively increased the size of subsequent samples by 10 until we reached a sample size of 120 individuals. Our analyses examined the results obtained using these samples of different sizes. We used 20 replicates of each sample size class, randomly selecting the males included each time. In the DFA models, the 11 PPDs were included as independent variables. We assumed that prior probability was equal for all groups since we used 20 calls from each individual. We also applied a cross-validation method (leave-one-out classification, otherwise known as the $U$ method). In this procedure, each case in the analysis is classified by functions derived from all the other cases except that one.

Using the same set of recordings, we calculated 11 PPDs similarity (Pearson's $R$ ) both within and between individuals. We compared all possible combinations of the 20 calls belonging to the same individual (190 combinations per individual) to calculate within-individual similarity. Between-individual similarity was calculated by comparing the average per-male 11 PPDs values for all possible pairs of males (122 males; 7381 different combinations). We then calculated the probability of being able to discriminate between two different males as their call similarity increased.

To determine the number of males that abandoned or changed their territories during the breeding season, we first calculated average nearest-neighbor distances in our study population $(280 \pm 177 \mathrm{~m})$. We assumed that a territory covered an area that spanned half the average distance to the nearest neighbor (6 ha and $140 \mathrm{~m}$, respectively). Such simplified definition of the territory seems to be reasonable, since our experience with playback experiments with Corncrake suggests that males actively defend only small area $(50-100 \mathrm{~m})$ around the calling place (Budka and Osiejuk, unpublished data). We then applied a conservative approach to determine territory shifts: we considered that a territory had been abandoned only if we found a different male within a previously defined territory during a subsequent recording session. We considered that a different male was present if the 
individual's call was less similar to the original call than would be expected based on within-individual 11 PPDs similarity.

Within-season movements were analyzed by constructing a similarity matrix using the mean 11 PPDs values obtained for each male; as above, the Pearson's $R$ coefficient was used as the similarity measure. We treated calls as belonging to the same male when their 11 PPDs similarity value was greater than 0.98 . We thus accepted the possibility that a male could be misidentified (likelihood of less than 0.014), in that two calls belonging to two different males could be classified as belonging to the same individual. Movement distances were calculated using ArcMap 9.3. The statistical analyses were performed using IBM SPSS Statistics 21. All $p$ values were two-tailed. We used classical definition of probability to calculate probabilities of events.

\section{Results}

Acoustic discrimination and identification

Our analyses showed that PPD can be used to acoustically identify individual male Corncrakes. Discriminant function analyses using the recordings from the 122 individually identified males yielded a high rate of correct identifications: $99.1 \%$ of calls were correctly assigned to the individuals that had produced them. When the leave-one-out classification method was applied, this rate was slightly lower $(98.7 \%)$. Furthermore, the classification rate declined marginally as sample size increased (Fig. 2). However, it always remained greater than $98 \%$, even at a sample size of more than 100 individuals.

Within-individual 11 PPDs similarity was always greater than 0.90 (average of $0.98 \pm 0.018$; Fig. 3a). Therefore, when two calls demonstrated an 11 PPDs similarity value of less than 0.90, it indicated that those calls belonged to different individuals. Between-individual 11 PPDs similarity varied from -0.68 to 0.99 (average of $0.41 \pm 0.383$; Fig. 3b). When pairs of males were compared, it was somewhat likely (probability $=0.14$ ) to find two different males that demonstrated an 11 PPDs similarity value of greater than 0.90 . However, the probability that two different birds would be more than 0.96 similar was less than 0.05 , and it was even less probable that two birds would be 0.98 similar (probability $<0.014$; Fig. 3c).

Territory abandonment and within-season movements

Within the 177 territories (defined as the area within a 140-m radius of a calling male) surveyed, we recorded calling males twice during the breeding season. In 31 cases, recordings were made during the same night, and in 146 cases, recordings were spaced out by 1-43 days (average of $21 \pm 12$ days). Using recordings made the same night, we found new males in 3 territories (10\%). Using recordings made during different nights within the same territory, we detected the presence of new males in 75 territories. This was $51 \%$ of all cases when we recorded again any male within a $140-\mathrm{m}$ radius from a previous calling location.

Our analyses show that less than $1.4 \%$ of male pairs demonstrated 11 PPDs similarity values of greater than 0.98. Therefore, we assumed that calls with similarity values of more than 0.98 were produced by the same male. Thus, we had the possibility of committing two types of errors: (1) assigning calls belonging to different males to the same individual (probability $<0.014$ ) and (2) assigning calls to different males when they belonged to the same individual (probability $<0.33$ ). Given these assumptions, we detected 700 movements of Corncrake males during the breeding season. Mean movement distance was $3.3 \mathrm{~km}$ $( \pm 2.7 \mathrm{~km})$; distances ranged from a few meters to $13.0 \mathrm{~km}$ (Fig. 4). We found that 76 individuals called from the same territories (having moved less than $140 \mathrm{~m}$ ) in subsequent recording sessions; in 149 cases, males moved less than $1 \mathrm{~km}$.
Fig. 2 The rate of correct classifications using acoustic identification as sample size varied. The results of the discriminate function analyses (employing the leave-one-out classification method) are presented. We performed 20 replicates, in which males were randomly selected, for each sample size class. The box depicts the median, the quartiles, and any extreme values

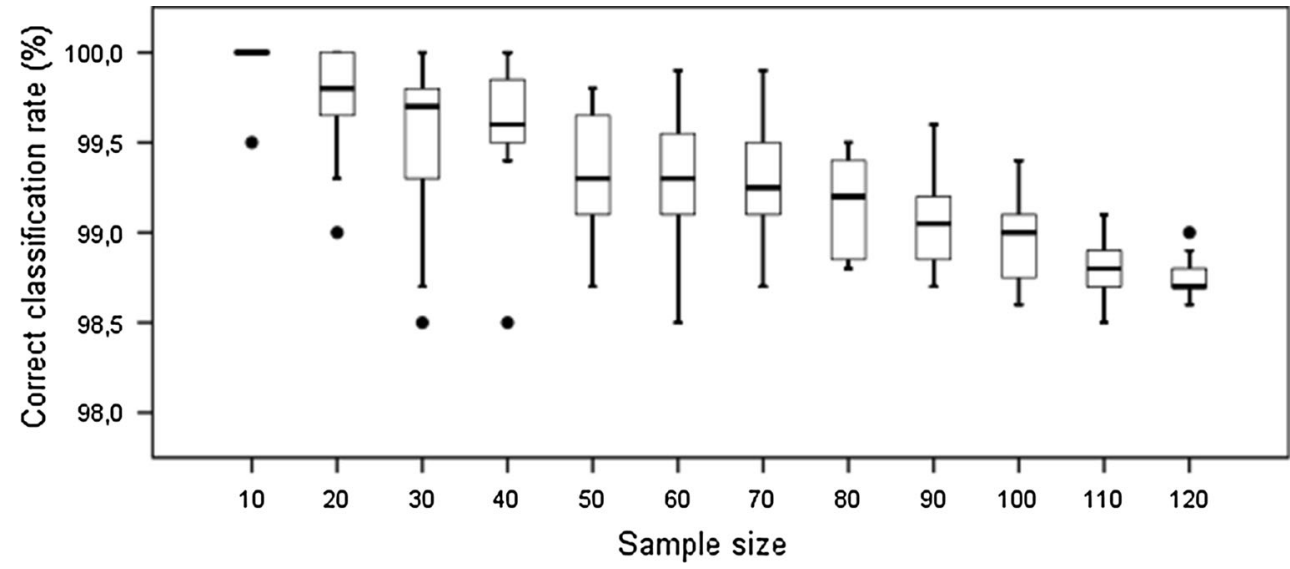



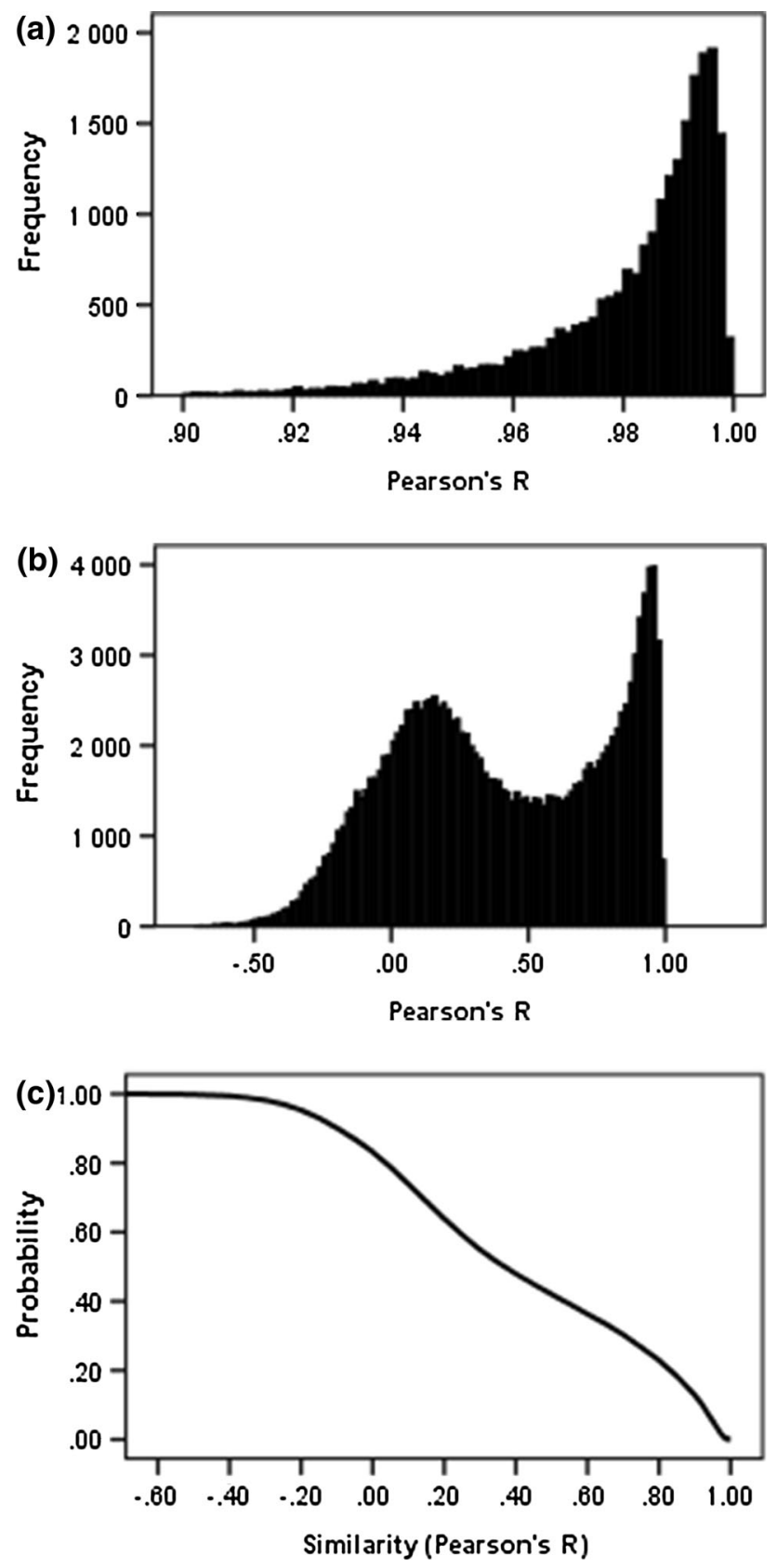

Fig. 3 Similarity (Pearson's $R$ ) among the first 11 PPDs in a Corncrake's call. The histograms show a the distribution of similarity values within individuals (all possible combinations of the 20 calls belonging to the same individual were compared for each individual; 122 males, 190 combinations per each male) and $\mathbf{b}$ the distribution of similarity values between individuals (the average per-male 11 PPDs values for all possible pairs of different males were compared; 122 males, 7381 combinations). c The probability of encountering two different males with a given degree of 11 PPDs similarity. These analyses are based on calls obtained from 122 individually marked males

\section{Discussion}

Certain characteristics that are widely considered to be individual-specific, such as fingerprints, DNA, or acoustic

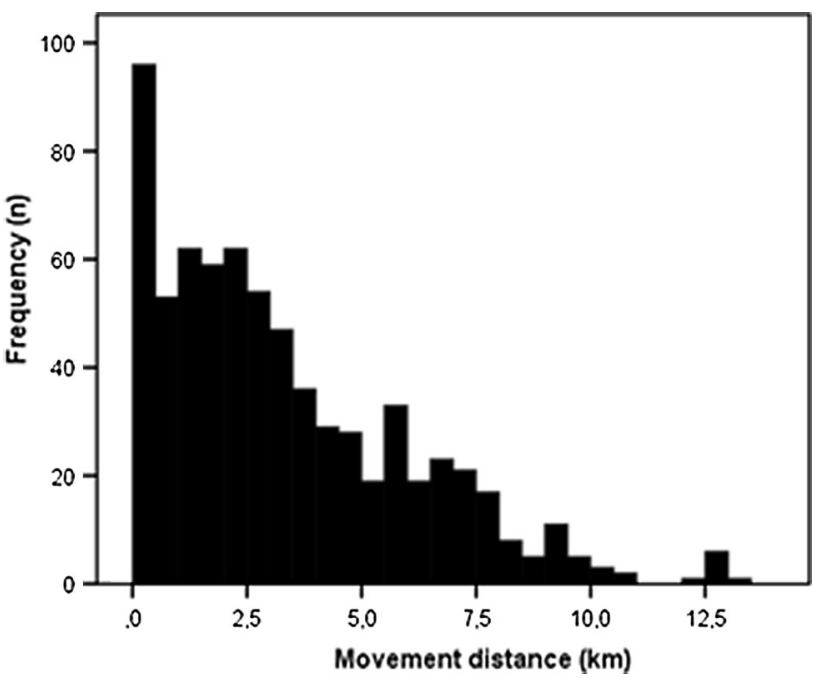

Fig. 4 Distribution of the distances moved by male Corncrakes in the Nurzec River Valley in 2012. When pairs of calls showed a similarity value of greater than 0.98 (Pearson's $R$ ), they were considered to come from the same individual

signatures, do not always result in a $100 \%$ classification rate (Osterburg 1964; Reilly 2001). There is always a small chance, albeit sometimes close to zero, that an individual will be misidentified. Therefore, the right question to ask is not whether we can identify an individual based on presumably unique characteristics, but rather how probable it is that we will encounter two indistinguishable individuals. In this study, the call feature we analyzed (a string of 11 PPDs) cannot be fully relied upon to unambiguously identify individuals. However, our results help clarify when and how researchers can use vocal individuality.

Discriminant function analysis is a commonly used statistical approach with which known numbers of individuals can be classified according to their call characteristics (Rebbeck et al. 2001; Terry et al. 2005). We used DFAs to determine how classification rate changed as sample size increased. Our results demonstrate that the rate of correct classifications decreased with increasing sample size (Fig. 2). However, it nonetheless remained high (more than $98 \%$ ) when our sample included all the 122 individually marked males used in our study. This result shows that vocal individuality can be successfully used to identify Corncrakes, as is the case for the Brownish-flanked Bush Warbler (Cettia fortipes) (Xia et al. 2012), even when dealing with more than 100 individuals. Thus, it is possible to discriminate between males in a local population when the number of individuals is known. This need to know the number of individuals included in the DFA largely excludes the possibility of this method being used in monitoring or censusing efforts.

We also showed that the specific call feature used in this study - PPD - demonstrates a high degree of within-individual similarity (0.90) in a continuous series of calls. This 
estimate of similarity, which is lacking in most studies (e.g., Grava et al. 2008; Garcia et al. 2012), can be used to discriminate between individuals: two calls with a similarity value of less than 0.90 can be considered to belong to different individuals. Simply put, the features of calls recorded in the same place can reveal whether or not those calls were produced by the same individual. At the same time, it is somewhat likely that two different individuals will produce calls that have a similarity value of 0.90 ( $p<0.14)$. Moreover, different males can generate calls with a similarity value of greater than 0.98 , although it is unlikely ( $p<0.014$; Fig. 3). These findings indicate that, when the number of individuals is unknown, it is impossible to unambiguously identify individual Corncrakes based on the PPDs of their calls. Thus, efforts aimed at monitoring individual Corncrakes over space and time cannot exploit differences in PPD. Moreover, PPD is only partially helpful in discriminating between individuals in censusing tasks. The appearance of a new male yields limited information: it is possible to say that a few different individuals visited a study area, but it is not necessarily possible to say whether a new individual was previously observed in the population (and therefore counted). As a consequence, it is rather difficult to use vocal individuality in censusing and monitoring efforts focused on Corncrakes (and probably other species as well), since researchers are dealing with populations of hundreds or thousands of individuals. Nevertheless, vocal individuality may be useful in the censusing and monitoring of small or isolated populations (Peake et al. 1998; Rebbeck et al. 2001; Delport et al. 2002), in which non-acoustic features can concurrently be used to identify individuals.

It is important to point out that the results of this study have yielded an estimate of the error rates associated with acoustic identification in the Corncrake. Consequently, it can be decided beforehand if the error rates are acceptable for the task at hand. For instance, acoustic identification can be exploited to study general behavioral patterns within populations. In this study, we found that male Corncrakes abandoned their territories during the breeding season and often moved short distances. This finding is not surprising given this species' breeding biology. Corncrakes are sequentially polygamous: males and females change mates over the course of the breeding season. Birds form pairs that last only a few days; after fertilization, the male leaves the female (Green et al. 1997). It is a good strategy for males to switch calling locations if they want to attract a different female, and location-switching by male Corncrakes has been observed in telemetry studies and in studies in which individuals have been marked (Tyler and Green 1996; Schäffer 1999). Using acoustic identification, we were able to show that this behavior was common in a Corncrake population. Therefore, we assume that Corncrake males do not actively defend large territories during the breeding season but rather periodically occupy and defend a few small territories.

Our results also clearly included some spurious displacements, i.e., when different birds were classified as the same individual, and these spurious displacements were included when we calculated movement distances. However, overall, the probability of committing this type of error was very low $(p<0.014)$. It is nonetheless important to point out that other, more traditional and common tracking methods, such as telemetry or individual marking, also have their disadvantages. They are usually relatively expensive and/or time consuming, which means that usually only a small number of individuals can be tracked. Conclusions based on small sample sizes may also be somewhat misleading. As a result, it could be useful to combine traditional and acoustic tracking methods when monitoring and censusing populations. It is always important to assess the limitations and potential errors associated with each method employed.

\section{Conclusions}

An individual-specific call feature-PPD_can be used to discriminate between individual Corncrakes. However, PPD similarity between males can be as high as within males (close to 1). As a result, it is almost impossible to be sure that the same individual is being tracked over space and time. Nonetheless, the acoustic identification method presented here yields an estimate of error rates and may still be useful in detecting general behavioral patterns (e.g., dispersal) within populations. Such patterns may then be examined using more expensive and reliable methods such as telemetry or individual marking, which can be used to follow a small subset of individuals. Moreover, this study shows that the results of vocal individuality studies with small sample sizes should be interpreted with care.

Acknowledgments We thank Lucia Turčoková and Sylwester Solaniuk for their help in the field, and Franz Bairlein and three anonymous referees for helpful comments on the manuscript. This study was funded by a grant from the Dean of the Faculty of Biology at Adam Mickiewicz University (GDWB-02/2011). The study was conducted in full compliance with the current laws of the Poland.

Open Access This article is distributed under the terms of the Creative Commons Attribution License which permits any use, distribution, and reproduction in any medium, provided the original author(s) and the source are credited.

\section{References}

Adi K, Johnson MT, Osiejuk TS (2010) Acoustic censusing using automatic vocalization classification and identity recognition. J Acoust Soc Am 127:874-883 
Ale SB, Morris DW, Dupucha A, Moore DE (2011) Habitat selection and the scale of ghostly coexistence among Arctic rodents. Oikos 120:1191-1200

Bächler E, Hahn S, Schaub M, Arlettaz R, Jenni L et al (2010) Yearround tracking of small trans-saharan migrants using light-level geolocators. PLoS ONE 5:e9566

Budka M, Osiejuk TS (2013) Habitat preferences of Corncrake (Crex crex) males in agricultural meadows. Agric Ecosyst Environ 171:33-38

Budka M, Mikkelsen G, Turčoková L, Fourcade Y, Dale S, Osiejuk TS (2014) Macrogeographic variation in the call of the corncrake Crex crex. J Avian Biol 45:65-74

Darden SK, Dabelsteen T, Pedersen SB (2003) A potential tool for swift fox (Vulpes velox) conservation: individuality of longrange barking sequences. J Mammal 84:1417-1427

Delport W, Kemp AC, Ferguson JWH (2002) Vocal identification of individual African Wood Owls Strix woodfordii: a technique to monitor long-term adult turnover and residency. Ibis 44:30-39

Doucette LI (2010) Home range and territoriality of Australian owletnightjars Aegotheles cristatus in diverse habitats. J Ornithol 151:673-685

Ekner A, Sajkowska Z, Dudek K, Tryjanowski P (2011) Medical cautery units as a permanent and non-invasive method of marking lizards. Acta Herpetol 6:229-236

Garcia M, Charrier I, Rendall D, Iwaniuk AN (2012) Temporal and spectral analyses reveal individual variation in a non-vocal acoustic display: the drumming display of the Ruffed Grouse (Bonasa umbellus, L.). Ethology 118:292-301

Grava T, Mathevon N, Place E, Balluet P (2008) Individual acoustic monitoring of the European Eagle Owl Bubo bubo. Ibis 150:279-287

Green ER, Rocamora G, Schäffer N (1997) Populations, ecology and threats to the Corncrake Crex crex in Europe. Vogelwelt 118:117-134

Hays GC, Christensen A, Fossette S, Schofield G, Talbot J, Marian P (2014) Route optimisation and solving Zermelo's navigation problem during long distance migration in cross flows. Ecol Lett 17:137-143

Hoodless AN, Inglis JG, Doucet JP, Aebischer NJ (2008) Vocal individuality in the roding calls of Woodcock Scolopax rusticola and their use to validate a survey method. Ibis 150:80-89

Jeffreys AJ, Wilson V, Thein SL (1985) Individual-specific "fingerprints" of human DNA. Nature 375:76-79

Kennedy AS, Zerbini AN, Gandilhon N, Clapham PJ, Adam O (2014) Local and migratory movements of humpback whales (Megaptera novaengliae) satellit-tracked in the North Atlantic Ocean. Can J Zool 92:9-18

Klenova AV, Volodina IA, Volodina EV (2008) Deut structure provieds information about pair identity in the red-crowned crane (Grus japonensis). J Ethol 26:317-325

Lopes RJ, Alves JA, Gill JA, Gunnarsson TG, Hooijmeijer JCEW, Lourenco PM, Masero JA, Prisma T, Pott PM, Rabacal B, Reis S, Sánchez-Guzman JM, Santiago-Quesada F, Villegas A (2013) Do different subspecies of Black-tailed Godwit Limosa limosa overlap in Iberian wintering and staging areas? Validation with genetic markers. J Ornithol 154:35-40

Mikkelsen G, Dale S, Holtskog T, Budka M, Osiejuk TS (2013) Can individually characteristic calls be used to identify long-distance movements of Corncrakes Crex crex? J Ornithol 154:751-760

Neubauer G, Zieliński P, Wojciechowski Z, Buszkiewicz E, Siekiera J, Siekiera A (2012) Leaving on migration: estimating departure dates of Barn Swallows Hirundo rustica from summer roosts using a capture-mark-recapture approach. Bird Study 59:144-154

Nietfeld MT, Barret MW, Silvy N (1994) Wildlife marking techniques. In: Bookhout TA (ed) Research and management techniques for wildlife and habitats: 147-159. The Wildlife Society, Bethesda

Osterburg JW (1964) An inquiry into the nature of proof: the identity of fingerprints. J Forensic Sci 9:413-427

Peake TM, McGregor PK (2001) Corncrake Crex crex estimates: a conservation application of vocal individuality. Anim Biodivers Conserv 24:81-90

Peake TM, McGregor PK, Smith KW, Tyler G, Gilbert G, Green RE (1998) Individuality in corncrake Crex crex vocalization. Ibis 140:120-127

Rebbeck M, Corrick R, Eaglestone B, Stainton C (2001) Recognition of individual European Nigtjars Caprimulgus europaeus from their song. Ibis 143:468-475

Reilly P (2001) Legal and public policy issues in DNA forensics. Nat Rev Genet 2:313-317

Ręk P, Osiejuk TS (2011a) No male identity information loss during call propagation through dense vegetation: the case of the corncrake. Behav Process 86:323-328

Ręk P, Osiejuk TS (2011b) Nonpasserine bird produces soft calls and pays retaliation cost. Behav Ecol 22:657-662

Rognan CB, Szewczak JM, Morrison ML (2009) Vocal individuality of Great Gray Owls in the Sierra Nevada. J Wildl Manag 73:755-760

Root-Gutteridge H, Bencsik M, Chebli M, Gentle LK, Terrell-Nield C, Bourit A, Yarnell RW (2014) Improving individual identification in captive Eastern grey wolves (Canis lupus lycaon) using the time course of howl amplitudes. Bioacoustics 23:39-53

Schäffer N (1999) Habitatwahl und Partnerschaftssystem von Tüpfelralle Porzana porzana und Wachtelkönig Crex crex. Ökol Vögel 21:1-267

Skórka P, Babiarz T, Skórka J, Wójcik JD (2006) Winter territoriality and fruit defence by the fieldfare (Turdus pilaris). J Ornithol 147:371-375

Specht R (2007) Avisoft-SASLab Pro, version 4.39. Avisoft Bioacoustics, Berlin

Terry AMR, McGregor PK (2002) Census and monitoring based on individually identifiable vocalizations: the role of neural networks. Anim Conserv 5:103-111

Terry AMR, Peake TM, McGregor PK (2005) The role of vocal individuality in conservation. Front Zool 2:10

Tsuji Y, Arum K, Widayati A, Hadi I, Suryobroto B, Watanabe K (2013) Identification of individual adult female Javan lutungs (Trachypithecus auratus sondaicus) by using patterns of dark pigmentation in the pubic area. Primates 54:27-31

Tyler GA, Green RE (1996) The incidence of nocturnal song by male Corncrakes Crex crex is reduced during pairing. Bird Study 43:119-214

Van Opzeeland I, van Parijs SM (2004) Individuality in harp seal, Phoca groenlandica, pup vocalizations. Anim Behav 68:1115-1123

Wahab A, Cin SH, Tan EC (1998) Novel approach to automated fingerprint recognition. IEE Proc Vis Image Signal Process 145:160-166

Walker M, Fureix C, Palme R, Mason G (2013) Co-housing rodents with different coat colours as a simple, non-invasive means of individual identification: validating mixed-strain housing for C57BL/6 and DBA/2 mice. PLoS ONE 8:e77541

Xia C, Lin X, Liu W, Lloyd H, Zhang Y (2012) Acoustic identification of individuals within large avian populations: a case study of the Brownish-Flanked Bush Warbler, south-central China. PLoS ONE 7:e42528 